„Bohemistyka” 2019, nr 3, ISSN 1642-9893

Aleksandra PAJĄK

DOI: $10.14746 /$ bo.2019.3.3

Uniwersytet Opolski

\section{...vzpomínám na něho ustavičně a přeji mu, aby se mu tatínek brzo vrátil. O (terapeutycznej) roli pamięci w korespondencji więziennej Jana Zahradníčka}

Keywords: epistolography, memory, trauma, Jan Zahradníček, Aleida Assmann Slowa kluczowe: epistolografia, pamięć, trauma, Jan Zahradníček, Aleida Assmann

\section{Abstract}

The article analyses letters written by a Czech poet - Jan Zahradníček during his stay in prison to his wife - Maria in the period 1951 to 1960 . A selection not only presents a record of life trauma resulting from long-time isolation and family tragedy (death of his two daughters) but also a testimony of the poet's memory, which enabled the author to survive hard times. Aleida Assmann's considerations (among others) constitute the starting point for memory description. The considerations primarily related to collective memory of societies affected with traumatic past could also be useful for the analysed individual case study.

Przedmiotem analizy są listy czeskiego poety Jana Zahradníčka wysyłane z komunistycznego więzienia do żony Marii w latach 1951-1960. Wybór to zapis zarówno życiowej traumy wynikającej z długoletniej izolacji oraz tragedii rodzinnej (śmierć dwóch córek), a jednocześnie świadectwo tego, że dzięki terapeutycznej roli (śmierć dwóch córek), a jednocześnie świadectwo tego, że dzięki terapeutycznej roli Assmann, które co prawda prymarnie odnosiły się do pamięci kolektywnej spoleczeństw dotkniętych traumatyczną przeszłością, ale mogą być także użyteczne dla rozpatrywanego tutaj studium przypadku jednostki.

Po roku 1989 wraz z upadkiem komunizmu oraz zniesieniem cenzury liczba wydawanych na czeskim rynku publikacji mieszczących się w szeroko rozumianej literaturze autentyku gwałtownie wzrosła (Machala 2005, s. 63). Niejednokrotnie wynikało to z faktu, iż dopiero po obaleniu żelaznej kurtyny badacze i edytorzy mogli zagłębić się w archiwach czy zbiorach prywatnych i wpisać się w ten sposób w to, co francuski historyk Pierre Nora definiuje jako ,,ponownie odnalezioną pamięć Europy Wschodniej" (Nora 2015, s. 62). W przypadku wielu autorów, których tekstów przez dekady komunizmu nie można było wydawać, epistolografia może dopełniać obrazu całości wcześniej ukrytego piśmiennictwa ${ }^{1}$.

Idac tropem dosłownie traktowanej ,,pamięci odnalezionej”, należy odnotować, że od roku 1995 do 2018 ukazało się sześć tomów korespondencji Jana Zahradníčka (1905-1960), poety, który poprzez naturalną analogię $\mathrm{z}$ biblijnym pierwowzorem nazywany był nieraz „czeskim Hiobem”. Trudno jednoznacznie tę ilość uznać za efekt jedynie pamięciowego zwrotu w humanistyce, tak wyraźnego od dłuższego już czasu, ale można założyć, iż jest to również odpowiedź na zainteresowanie czytelnicze. Sa to zbiory zawierajace listy wymieniane z Janem Čepem (Čep, Zahradníček 1995, 2000)², Františkiem Halasem (Neni dálky... 2003), Timotheusem Vodičką (Je to s tím Akordem... 2017) i Františkiem Hrubínem (Ve znamení »jadis«... 2018).

W niniejszym artykule ze względu na obszerność materiału ${ }^{3}$ korpus analizowanych tekstów zostanie zawężony jedynie do listów, jakie wysyłał Zahradníček od czerwca 1951 do maja 1960 roku z komunistycznego więzienia do żony Marii ${ }^{4}$ (Zahradníček 2008). W literatu-

${ }^{1}$ W klasycznym ujęciu Stefanii Skwarczyńskiej list jest uznawany za ,autonomiczny rodzaj literacki" i traktowany jako część literatury stosowanej (Skwarczyńska 1937)

${ }^{2} \mathrm{Na}$ temat m.in. tej korespondencji pisałam już wcześniej (Pająk 2014).

${ }^{3}$ Korespondencją pomiędzy Zahradníčkiem a Halasem zajmuję się w podobnym kontekście w artykule Kouzlo dálky i mechanismus vináren a kaváren - uwagi o (nie)pamięci w korespondencji Jana Zahradníčka z Františkiem Halasem, złożonym do druku w czasopiśmie „Slavica Wratislaviensia”.

${ }^{4}$ Gwoli ścisłości należy dodać, iż na końcu niektórych tekstów autor zamieszcza fragmenty skierowane do syna Jana (zwanego przezeń konsekwentnie Jakoubkiem), 
rze czeskiej chyba najbardziej rozpoznawalnym dziełem przynależnym do epistolografii więziennej byłyby zapewne późniejsze Dopisy Olze Václava Havla (funkcjonujące przed rokiem 1989 także w samizdacie), ale w szeregu takich autorów można wspomnieć również jeszcze np. Rudolfa Battka, Josefa Šimsę czy Ladislava Hejdanka (Baluch 1993, s. 6).

W przypadku poetycko zatytułowanego zbioru Mezi nás prostřená noc (Zahradníček 2008) mamy do dyspozycji jedynie teksty nadawcy, co stanowi jedną z wyraźnych różnic wobec pozostałych (zarówno wcześniejszych, jak i późniejszych publikacji zawierających korespondencję autora Znamení moci). Listy Marii Zahradníčkovej nie zachowały się, jak można przeczytać w dołaczonym do tego wydania eseju Jiřego Hanuša (Hanuš 2008, s. 329). Miejsce naturalnego korespondencyjnego dwugłosu, zajmuje quasi-monolog, zdeterminowany przez czynniki zewnętrzne, głównie limitowaną częstotliwość wymiany oraz ściśle określony format i długość tekstu. W kontekście epistolografii więziennej ów rygor nabiera szczególnego znaczenia, choć Jan Trzynadlowski zauważa, iż fizyczne rozmiary listów są w ogóle sprawą wyraźnej konwencji albo narzuconej struktury (Trzynadlowski 1977, s. 82). Należy również zaznaczyć, iż na tle pozostałych wyborów ten niesie ze sobą bardziej uniwersalny przekaz. Istotną różnicą jest również fakt, iż zbiór, wyrastający z kompletnie odmiennej sytuacji osobistej, w jakiej znalazł się poeta, odizolowany od rodziny na długie lata, to świadectwo i zapis psychicznych śladów tej rozłąki. To korespondencja rozpięta jeszcze mocniej między sui generis auto- a biografię ${ }^{5}$, w której warunkiem przeżycia pozostaje wszak pamięć. Do podobnych wniosków skłania się Jitka Bednářová, pisząc:

kilka jest też niemal w całości do niego adresowanych i wówczas tylko wstępne formuly sa zwrócone do żony. Sam nadawca nazywa je „listami o przyrodzie”, oddając tak w dużym stopniu ich charakter.

${ }^{5}$ Wspomniany Jan Trzynadlowski, badając powiązania między „małymi formami literackimi (m. in. listem a pamiętnikiem), podkreśla wyraźnie: ,„»ja« piszącego [w listach - A.P.] wybija się na plan pierwszy, między biografią w ścisłym tego słowa
Zahradníčkovy vězeňské epištoly stojí v určitém kontrastu vůči jeho dopisování během aktivních literárních let a zejména vůči období redigování Akordu, kdy básník odloučený na Vysočině vyjednával většinu redakční a nakladatelské agendy písemně. Ve vězeňském prostředí všechno vnější odpadá: zůstává svět vnitřní, svět v plném slova smyslu duchovní. Není divu, že svůj myšlenkový kapitál Zahradníček těží převážně ze vzpomínek (Bednářová 2008, s. 69).

Z obszernego wydania, zawierającego 250 listów, pochodzi również cytat otwierający tytuł niniejszego artykułu. Sugeruje, iż w tak niesprzyjających warunkach, w jakich Zahradníček spędził niemal dekadę, jedną z możliwości przetrwania, stanowiły wspomnienia, o których niemiecki pisarz Jean Paul (1763-1825) stwierdził, iż są jedynym rajem, z którego nie można człowieka wypędzić (za: Kratochvil 2008, s. 5).

Oczywistym jest, iż ze względu na adresatkę publikacja Mezi nás prostřená noc zawiera korespondencję o charakterze zdecydowanie bardziej intymnym i być może należałoby ją uznać za zbiór listów miłosnych, który powinien pozostać w archiwum rodzinnym ${ }^{6}$. Czytelnik ma nieodparte wrażenie, iż większą rolę odgrywa tutaj odbiorca, na którym skupiona jest uwaga piszacego, choć i tutaj ponownie znaleźć można wiele argumentów na poparcie tezy, iż epistolografia to specyficzny rodzaj autobiografii z właściwym dla siebie pierwiastkiem autokreacji.

Trzeba także dodać, iż wyraźną cezurę tworzy tragedia, jaka spotkała rodziców w 1956 r., kiedy w wyniku zatrucia grzybami zmarły dwie małe córki, a Zahradníček na krótko był wówczas w domu, po

znaczeniu a faktami wokół niej zgrupowanymi albo nie ma granicy, albo ma ona nader płynny charakter. Właśnie dzięki temu biografizm jest dla listu i całego ich zbioru faktem primo loco z wszystkimi tego następstwami” (Trzynadlowski 1977, s. 94).

${ }^{6}$ Watpliwości tego typu nie mieli wydawcy tomu (Martina Sendlerová, Milan Řepa) lub nie zawarli ich w komentarzu. Por.: Ediční poznámka (Zahradníček 2008, s. 303-305). Z kolei Jitka Bednářová zauważa: my čtenáŕi můžeme sledovat tento jedinečný př́nos tradici české milostné lyriky, s úžasem, do jakých hloubek a výšin se může vzepnout láska manžela a otce" (Bednářová 2005, s. 71). 
czym ponownie (wbrew obietnicy skrócenia kary) musiał wrócić za kraty. Listy pisane po tym dramacie (stanowiące znaczącą większość opublikowanych) są jeszcze bardziej przejmującym zapisem losów rodziny, a do słów kluczy powracających w tomie należeć z pewnością będą te metaforycznie oddające ogrom cierpienia i niemal fizycznego bólu rozłąki, jak ofiara, wspólny / ciężki krzyż, straszny / trudny egzamin czy ciężkie brzemię. Traumatyczną tonację, czasem eksplikowaną językiem biblijnych konotacji, nieco tylko łagodzi fakt, iż po tym krótkim pobycie w domu, małżonkom urodzi się kolejna córka.

Warto w tym miejscu zauważyć, iż być może - wbrew oczekiwaniom czytelniczym - nie znajdziemy zbyt wielu odniesień do Pisma Świętego, stanowiących rodzaj egzegezy zaistniałej sytuacji. W jednym z pierwszych listów Zahradniček jednak porównuje swój los do patriarchy Abrahama:

[...] snad jsem si toho málo považoval, toho štěstí s Vámi, těch několika nejšt’astnějších let v celém mém životě, bylo mi to odňato, ale já pevně doufám v Boží milosrdenství, že jenom na čas a že se s Vám zase shledám. Vzpomínám si často na obět' Abrahamovu na malého Izáka, kterého Bůh od něho nepřijal a spokojil se jenom jeho dobrouvưlí a jeho poslušností (Zahradníček 2008, s. 16).

Echo takiego podejścia czytelne jest także w wierszu Obět’ Abrahamova z tomu Čtyři léta. Z kolei w liście z 25 sierpnia 1957 roku wspólnotę cierpienia, po śmierci córek, zawiera w krótkiej eksklamacji „Dva ubozí Jobové!” (Zahradníček 2008, s. 105), w następnym zaś wyraża nadzieję, iż po latach cierpienia zostanie ono wynagrodzone niczym Hiobowi (Zahradníček 2008, s. 128). Podobnych miejsc nie można jednak zlokalizować zbyt wiele, a jeśli już są, to ich centrum stanowią z reguły obie wspomniane postacie ze Starego Testamentu.

Specyficzna dialektyka pamięci, rozpięta między relatywnie ujmowane przestrzenne kategorie blisko - daleko, da się zawrzeć w obrazie „wojny”, jaka toczy się między „dobrymi i złymi wspomnieniami” (Zahradníček 2008, s. 106), co dość dobrze oddaje charakter całości. Niezbyt liczne są momenty, w których poeta boi się wspominać dobre chwile w tak niesprzyjających warunkach zewnętrznych, jakie tworzy więzienie, jakby obawiając się czegoś w rodzaju profa- nacji (Zahradníček 2008, 38-39). Częściej to pozytywne obrazy przeszłości, przede wszystkim wspólnie dzielony czas od momentu ślubu aż do zatrzymania z centralnym obrazem szczęśliwych lat spędzonych w Brnie, są tym, co pozwala przetrwać długoletnią izolację. Złe wspomnienia, należy zauważyć, związane np. z aresztowaniem czy pobytem w więzieniu raczej trafiają do zakamarków niepamięci, choć należy brać pod uwagę kontekst, w jakim listy są pisane; wszystkie przechodziły przez podwójne sito auto- i cenzury, co zresztą sporadycznie, bodajże dwukrotnie, jest wyrażone wprost $^{7}$.

Autor nieraz dyscyplinuje również sam siebie, by nie powracać do smutnej przeszłości, choć nie zawsze się mu to udaje. Tendencja do rozdrapywania ran dochodzi do głosu zwłaszcza w momentach gorszej kondycji fizycznej czy podczas kolejnych spędzanych za murami więzienia świąt. Przeciwwaga są wówczas przywoływane w pamięci pozytywne obrazy wspólnych chwil lub projekcje tego, jak będzie wyglądać przyszłość rodziny po powrocie poety ${ }^{8}$. Zadomowienie, za którym tęskni, odnosi się zarówno do konkretnego miejsca, ale - w typowy dla dwudziestowiecznego podejścia do nostalgii sposób - oddaje także stan umysłu (Zaleski 2004, s. 15).

Pamięć jest pobudzana przez autora do pracy niemal rytualnie, najczęściej wieczorem o godzinie dziewiątej niczym w liturgii godzin

\footnotetext{
${ }^{7}$ Relacjonując jeden ze snów o charakterze nieco erotycznym, pyta się, między wierszami przemycając następującą uwagę: „hodí-li se do dopisu, který čtou i jin lidé?" (Zahradníček 2008, s. 77). Drugi raz myśl o cenzurze nie jest aż tak zawoalowana: „Ale je to tak těžké, když se o mnohých věcech nedá prostě psát a o jiných zase nesmí" (Zahradníček 2008, s. 206).

${ }^{8}$ Co zresztą nie wydaje się być czymś wyjątkowym. W 120. liście Václava Havla do żony Olgi czytamy: „Co będzie dalej, nie wiem. Na razie wiem tylko, że na przekór wszystkim doświadczeniom, jak dotąd - chyba - nie zrobiłem z siebie błazna, a więc zachowałem swoją tożsamość, dowiodłem swojej wiarygodności i uratowałem swoją godność. [...] Nie jest wcale pewne, czy dzięki temu jeszcze coś dobrego napiszę: ale wiem dobrze, że w przeciwnym wypadku już na pewno niczego dobrego bym nie napisał. A więc nie wiem, co będzie dalej. Przyszłość jest otwarta księga - jestem pełen nadziei, watpliwości, obaw, niepewności, planów, postanowień” (Havel 1993, s. 129).
} 
kompleta podsumowująca dzień (zob. np. Zahradníček 2008, s. 117). Obejmuje nią, poza najbliższym kręgiem rodzinnym, który jest obecny właściwie niezmiennie w monotonnej enumeracji w konwencjonalnych formułach wstępnych lub końcowych każdego niemal listu, przy okazji świąt patronalnych, rocznic, jubileuszy, także członków bliższej i dalszej rodziny, przyjaciół i znajomych ${ }^{9}$. Pozytywne wspomnienia (również w postaci zapewnień o modlitwie) są niczym przęsła mostu, budującego więź między światem TAM (daleko) a TUTAJ (blisko). Skracają czy minimalizują dystans nieustannie odczuwalny w więziennej rzeczywistości. Poczucie to jest wielokroć artykułowane i eksplikowane dzięki duchowej, a nie fizycznej bliskości, jak we fragmencie przywołującym „odbity w pamięci” wrześniowy dzień sprzed 16 lat:

A bylo to $\mathrm{s}$ Tebou krásné, drahá Mařenko, a bylo to $\mathrm{s}$ Tebou, i když jsi tady $\mathrm{v}$ žaláři tolik let se mnou nebyla, protože když se s někým spojíme, zůstáváme s ním spojení i přes dálku, přes tloušt'ku zdí a zlobu času (Zahradníček 2008, s. 102).

Zaraz w kolejnym liście, przypominając sobie nagle zapomniany wcześniej obraz syna śpiącego w słońcu, zauważa, że „,věci krásné zůstávají tak blízko, jako by to bylo včera" (Zahradníček 2008, s. 103) Marek Zaleski trafnie oddaje ten proces, zauważajacc, iż ,[m]ityzacji ulega [...] czynność wspominania, zmieniając się w rytuał ocalania od zapomnienia, wydobywania z przepaści niepamięci, wyzwolenia przeszłości”, a [p]owracający w przeszłość [...] przypomina mitycznego bohatera: podejmuje wyprawę w głąb labiryntu, za jedyne wsparcie mając wątłą i niepewną nić pamięci” (Zaleski 2004, s. 28).

Katalizatorem wspomnień może być niemal wszystko, głównie są to bodźce sensualne: $n p$. dym z komina widziany podczas więziennego spaceru, usłyszany przez zakratowane okno śpiew ptaka, zapomniany przez żonę czarny, ciepły sweter ${ }^{10}$ towarzyszący mu później

9 ,[...] jako si vůbec vzpomínám na všechny svátky a výroči”” (Zahradníček 2008, s. 102)

${ }^{10}$ Zahradníček dopuszcza się w tym przypadku swego rodzaju pia fraus. W kilku listach opisuje, iż zapomniany przez żonę podczas widzenia sweter to rodzaj suple- podczas zimnych nocy. Ale rolę tę pełnią również posyłane fotogra$\mathrm{fie}^{11}$. Wielokrotnie domaga się ich, jednocześnie zwracając uwagę na możliwość ich „opatrzenia”, przyzwyczajenia się do obrazów na nich zawartych, mogącego wypierać te pozostające $\mathrm{w}$ pamięci $\mathrm{z}$ czasu wspólnie spędzonego. Tego typu uwagi dotyczyły głównie żony, przez całą korespondencję Zahradníček wyraża żal z powodu niewielkiego kontaktu z dziećmi, zwłaszcza z córkami, których niemal nie znał, więc tym bardziej fotografia była tutaj jedynym medium bliskości. Prosząc o przesłanie kolejnych zdjęć (otrzymywane po jakimś czasie odsyłał), porusza kwestię słabnących obrazów najbliższych, pisząc w grudniu 1957 roku:

Tou strašnou odloučeností se tolik věcí z paměti vytrácí, člověk potřebuje nějaké opory, a tenkrát v těch prvních letech jsme byli tak št’astni. Snad najdu něco z toho i na těch obrázcích, $v$ Tvých očích a na Tvých rukou. Ach, přál bych si, aby se ta léta vrátila, jako vrátil Bůh Jobovi po letech strašných zkoušek rodinu, děti a stáda, ale nechtěl bych být už nikdy takový, jaký jsem býval tenkrát, tak nedbalý, roztržitý a sobecký. Jak málo jsem si vážil těch drahocenných dní, kdy jsem mohl být s Tebou pod jednou střechou a u jednoho stolu po tolika letech skrývání a oddalování. Má drahá a milovaná Mařenko, kolikrát jsem Tě už v duchu za ta léta žalářní prosil za odpuštění nebo aspoň shovívavost, když si vzpomeneš na tehdejší mou pošetilost, s jakou jsem mrhal časem i zdravím, jezdě a chodě po všelijakých schůzkách a sedánkách. Jediná chvíle strávená s Tebou je mi ted' dražší než celé dny bez Tebe. Vzpomínáš, jak jsem sedával u stolu v tom polozařízeném bytě a jak jsem Ti předčítával, když se mi podařilo něco udělat. Proč jsem to nedělal častěji a soustavně? Proč jsem tak rychle zpohodlněl a bral samozřejmě, zač jsem měl děkovat na kolenou? (Zahradníček 2008, s. 128).

Powyższy, dłuższy cytat dobrze ilustruje często powtarzającą się strategie autoprezentacji nadawcy. Da się go przedstawić jako sekwencję następujących elementów: strach przed utratą pamięci (czy też

mentacji fizycznej nieobecności, później jednak przyznaje się, iż dostał go dopiero po długim czasie od pozostawienia.

${ }^{11} \mathrm{Nie}$ w każdym miejscu pobytu było dozwolone posyłanie fotografii czy innych dodatków, jak np. obrazków dzieci. Obostrzenia dotyczyły także adresatów, choć np. do skazanego mogli pisać również inni krewni. 
może bardziej adekwatnie - słabnącą pamięcią), wypierane, traumatyczne doświadczenie osobiste, powiązane jednak z teodyceą (poprzez przywołanie historii Hioba) i niewyartykułowanym wprost pytaniem unde malum?, dalej konfesyjny rachunek sumienia, lament, prośba o odpuszczenie win i zaniedbań.

Sam poeta również akcentuje wielorakość bodźców uruchamiających pamięć, kiedy pisze, wierząc, iż czas trudnej próby wkrótce się skończy:

Zabývám se tím, že z útržků vzpomínek, z doteků, slov a pohledů rekonstruuji prostou a krásnou skutečnost být s Tebou a u Tebe (Zahradníček 2008, s. 214).

Parę lat wcześniej wypowiadał się w podobnym tonie:

Vzpomínám na Vás vždycky večer kolem deváté a snažím se svou obraznost přenést $\mathrm{k}$ Vám do kuchyně, když se modlíte a připravujete ke spánku. Cítím někde i vůni jídla, které jste měli k obědu a vidím Tě, jak zíváš a otřásáš se chladem. Místo mne je tam ovšem s Vámi víc než šestileté prázdno po mně, ale zvykli jste si už, nedá se nic dělat, i já jsem si zvykl. Je to ovšem zvyk, který bychom rádi a ochotně od sebe odvrhli. Zatím se držím zběsilé svých představ a vzpomínek na to, co jsme společně prožili, opakuji si to, těším se až Ti to budu jednou, a to brzo vypravovat [...] (Zahradníček 2008, s. 117).

Oba fragmenty współbrzmią z postrzeganiem funkcjonowania fenomenu pamięci u Giambatisty Vico, jak przypomina Manfred Weinberg. Dla autora Nauki nowej pamięć (memoria), wyobraźnia (fantasia) i inwencja (ingegno) tworzą nierozerwalną triadę o funkcji kulturotwórczej, dzięki której z poszczególnych faktów wspomnieniowych tworzona jest konsekwentna i spójna historia (Weinberg 2015, s. 21). W cytowanych urywkach (podobnych można znaleźć znacznie więcej) autor przywołuje co najmniej dwa elementy koncepcji Vico, ale trzeci (ingegno) również wydaje się w nich może nie immanentnie, a jednak zawarty.

Gasnące pod wpływem czasu obrazy z przeszłości ewokują nieraz wyrzuty sumienia, a zarazem bezradność wobec nieuchronności czy raczej niemożności zmiany beznadziejnej z ludzkiego punktu widzenia logiki sytuacji. Obok zapisów snów (będących z reguły wizją żony i szczęśliwych chwil z nią spędzanych) artykułowany - choć rza- dziej - jest również rozproszony na tysiące fragmentów, wymuszonych przez zewnętrzne limity prowadzonej korespondencji strach czy może nawet obsesja przed byciem zapomnianym i utratą własnej pamięci ${ }^{12}$. Tonacja dolendo - jak było wspomniane - mocniej dochodzi do głosu po śmierci córek. Nieco tylko przełamana zostaje informacja o spodziewanym kolejnym dziecku i najczęściej dramat rodziców (sam poeta, posługując się cytatem, określa go symptomatycznie i lakonicznie jako „wygnanie z raju”) będzie tym drugim wydarzeniem niejako równoważony. Wówczas pojawia się jedna $\mathrm{z}$ niewielu aluzji literackich, kiedy tragiczne doświadczenie życiowe Zahradníček porównuje do Piekła Dantego ${ }^{13}$. Dostrzega naturalny proces przeżywania żałoby i traumy, nie nazywając może tego wprost:

Takovým připomínkám se budeme marně bránit, budou se nám stále vracet, budou jen méně drásavé a jaksi tišší a tesknější. Jen kdybych už mohl být s Tebou, abychom společně odráželi ty návaly zármutku, které přicházejí tak neočekávaně (Zahradníček 2008, s. 93).

W tym kontekście wspólnoty rodzinnych wspomnień przychodzi na myśl uwaga Paula Ricoeura, który wydzielając dla bliskich osobny szlak atrybucyjny pamięci, zauważa:

[...] więź z nimi przecina w poprzek, do tego wybiórczo, zarówno relacje pokrewieństwa, jak i powinowactwa, jak i stosunki społeczne [...] Oprócz równoczesności „wspólnego dorastania” dochodzą jeszcze dwa „wydarzenia”, które wyznaczają granice ludzkiego życia - narodziny i śmierć. Pierwsze wymyka się [mojej] pamięci, drugie wyznacza granicę [moich] planów (Ricoeur 2012, s. 173).

12 Ponadto do wyraźnie powracających motywów zaliczyć można: ręce żony (omawia ten wạtek również Bednáŕová 2005, s. 72-73), pozostawiony przez nią już przywołany sweter czy pierwsze siwe włosy, które zauważyła u siebie oraz oczywiście śmierć córek, narodziny kolejnej, a także wcześniej kwestie wychowawcze głównie w odniesieniu do syna.

${ }^{13}$ Nieprzypadkowo zresztą, poeta bowiem współpracował z Otokarem Bablerem nad przekładem Boskiej komedii Dantego. Więcej na temat samego thumaczenia, udziału Zahradníčka oraz wpływu oryginału na poetykę późnej twórczości autora zob. Osolsobě 2005, s. 77-90. 
Tutaj zewnętrzny splot tragicznych wydarzeń, wywołuje nieoczekiwane połączenie śmierci córek z narodzinami kolejnej i niemal zawsze w takiej dychotomicznej paraleli będzie się pojawiał ten wątek w listach Zahradníčka.

Jednostkowemu, konkretnemu losowi własnej rodziny w izolacji muszącej sobie radzić z traumą, uznawaną za jedną z najistotniejszych kategorii kulturowych XX wieku ${ }^{14}$, poeta stara się nadać wymiar uniwersalny, pisząc chociażby o wspólnocie cierpienia. Znajdziemy jednak wiele miejsc, które wskazują, iż nie zawsze uniwersalizacja ta przynosi zamierzony efekt $\mathrm{w}$ postaci ulgi. Strategia powracania i (re)konstruowania (to chyba bardziej adekwatne określenie w przypadku ojca, niebędacego bezpośrednim świadkiem i uczestnikiem tragedii) bolesnych wydarzeń, to wyraz tego, jak wstrząśnięta pamięć stara się poprzez szok uwolnić czy wyzwolić swe środki wyrazu (Miller 2015, s. 302). Ale należy zauważyć, iż mimo pewnych symptomów być może „laicko rozumianej traumy” (Alexander 2015, s. 99), spowodowanej śmiercią dzieci, nie ma w korespondencji zapisów snów tego wydarzenia, znanego wszak tylko z relacji najbliższych.

Ów powracający, a nawet monotonny porządek przypominania sobie i adresatce faktu zgonu Klarki i Zdislavki wydaje się być wariantem tego, co Aleida Assmann uznaje za trzeci model, jak postępować $\mathrm{z}$ traumatyczną przeszłością. To wspomnienie jako godzenie się z nią (Assmann 2015, s. 245 i n.). Uznając konieczność zaistnienia krytycznej sytuacji przejścia w celu uzyskania oczyszczającego i terapeutycznego efektu końcowego, badaczka podaje dwa przykłady. Pierwszym jest spowiedź, gdzie wyznaje się (czyli de facto przypomina) grzechy, aby o nich po formule absolutio zapomnieć (odpowiadałby temu wcześniej analizowany dłuższy cytat). Analogiczną rolę pełni artystyczny proces katharsis - ponowne przedstawienie bolesnej przeszłości na scenie (dosłownej czy metaforycznej) pozwalające raz jeszcze odczuć jej ciężar, a tym samym ją pokonać. Odsyłacze Zahradníčka do rodzinnej tragedii, w tym obraz samego siebie, wspierające-

${ }^{14}$ Refleksja autorstwa Cathy Caruth (pod. za: Kratochvil 2015, s. 93). go się o żonę nad grobem córek, sytuują się gdzieś między dwoma wariantami przywoływanymi przez Assmann.

W kontekście refleksji nad pamięcią, znaczące jest, iż w ostatnim wysłanym liście autor tak mocno akcentuje proces zapomnienia. Zdając sobie sprawę, iż kończy się udręka izolacji, chce sam sobie dostarczyć bodźców do przełamania jej wybiórczości, ale z przykrością konstatuje, iż nawet codzienność powoli, ale jednak konsekwentnie z niej zaczyna znikać:

Zapomněl jsem už na kterési vůně, na vůni domácí kuchyně, vůni žehleného prádla, ještě na Mírově při jedné návštěvě ležela mezi námi Tvá cestovní brašna a tam mi z ní zavonělo domovem, a to všechno bude ted' kolem mne, ty dávné vůně, ty dávné barvy, které mi všechny ř́kají něco o Tobě (Zahradníček 2008, s. 255).

Oba paradygmatyczne sposoby godzenia się z ciężarem przeszłości: wspomnienie kontra zapomnienie (niepamięć), zachowanie przeszłości kontra ukierunkowanie się na przyszłość, jakie są punktem wyjścia dla rozszerzonej następnie przez Aleidę Assmann typologii ${ }^{15}$, w różnych konfiguracjach pojawiają się w epistolografii Zahradníčka i świadczą o tym, że jest ona nie tylko świadectwem jednostkowych losów czeskiego poety, ale także obrazem w dużej mierze uniwersalnym.

Pod koniec rozważań nad kwestią pamięci w epistolografii więziennej Jana Zahradníčka, powraca pytanie o moralne przyzwolenie na zaglądanie do nieswojej korespondencji, prymarnie skierowanej wszak do jednego, konkretnego adresata ${ }^{16}$, co zresztą podobnie eksponuje Małgorzata Czermińska, zauważając:

\footnotetext{
${ }^{15}$ Badaczka w przywoływanym już eseju wyróżnia cztery modele, odnosząc je jednak do pamięci kolektywnej. Są to: dialogiczne zapomnienie (dialogische Vergessen), wspominanie jako przeszkoda zapomnienia (erinner, um niemal zu vergessen), wspominanie jako godzenie się $\mathrm{z}$ przeszłością (erinnern, um zu überwinder), dialogiczne wspominanie (dialogische Erinnern) (Assmann 2015 , s. 240-253).

${ }^{16}$ Cytowany już Jan Trzynadlowski słusznie podkreśla, iż „odbiorca realny jest równocześnie odbiorcą optymalnym” (Trzynadlowski 1977, s. 85).
} 
Lektura cudzej korespondencji wydanej drukiem, stwarza zupełnie specyficzną sytuację odbiorcy (Czermińska 1975, s. 37).

Pytanie to pojawiło się kilka lat temu podczas mojego pierwszego spotkania z analizowanym tutaj zbiorem. Ówczesna lektura wywołała we mnie bardzo ambiwalentne odczucia wobec faktu śledzenia pełnej głębokiej intymności, choć jednostronnej, relacji z czasów, które nigdy nie powinny się wydarzyć. Poza potocznym rozumieniem intymności, o jakim tutaj mowa, badacze zwracają uwagę ponadto na kolejne aspekty tej kategorii, kluczowe dla epistolografii:

[...] intymność informacji listowych ma postać dwojaką: jest to intymność sensu stricte, tzn. odnosząca się do spraw w zasadzie niepodawanych do wiadomości szerszej poza kimś bliskim (poufność, poufałość) oraz po wtóre - intymność spraw uznawanych przez piszących za jedynie ich interesujące (Trzynadlowski 1977, s. 94).

Niezależnie od tej ambiwalencji, kiedy czytałam ten zbiór, ciągle właściwie powracała kwestia, czy my - czytelnicy w przypadku takiego wyznania miłosnego rozpisanego na swego rodzaju 250 epistolograficznych strof - mamy prawo w ogóle doń zaglądać? Od podobnej uwagi, podkreślającej ogromny potencjał emocjonalny, rozpoczyna tekst poświęcony więziennej korespondencji poety cytowana już Jitka Bednářová:

Dopisy v nichž je Zahradníčkův vězeňský úděl zachycen, považuji bez nadsázky za jeden z nejkrásnějších a nejvroucnějších epistolografických souborů české literatury: psychologicky si př́liš nedovedu představit člověka, který by je četl se srdcem otrlým (Bednářová 2005, s. 67).

Warto zatem powrócić raz jeszcze do pytania: czy taka lekturę usprawiedliwia status badacza? Jan Trzynadlowski częściowo odpowiada na tego typu wątpliwości, akcentując, iż ,zbiór listów z biografii bezpośrednio wynikający sprawom biograficznym przede wszystkim jest poświęcony i stanowi bezcenne źródło do jej poznania" (Trzynadlowski 1977, s. 94), Małgorzata Czermińska zaś poza takim typem podejścia, wskazuje na dwa dodatkowe ${ }^{17}$. W przypadku Za-

17 „Mamy więc trzy możliwości: albo traktować list jako podręczny magazyn informacji o autorze, środowisku lub epoce, od czasu do czasu wtrącając komplement hradníčka niewątpliwie sięganie do takiego źródła wzbogaca obraz autora $^{18}$, poza wcześniejszymi obliczami, wytworzonymi na podstawie jego twórczości, również o twarz ojca zatroskanego, ale i ingerującego w sprawy wychowawcze (zwłaszcza w przypadku najstarszego syna), męża podpowiadającego żonie, jak ma się modnie ubierać (wiedzę zyskiwał z czasopism dostępnych $\mathrm{w}$ więziennych bibliotekach, gdzie często pracował), jak zdrowo gotować i żyć oraz projektującego wspólną przyszłość, którą nie będzie im dane długo się cieszyć. Niedługo po powrocie $\mathrm{z}$ więzienia poeta bowiem w konsekwencji przebytych chorób i nadwyrężonego tam zdrowia, umiera, opuszczając rodzinę na zawsze. Niemniej można pokusić się o przypuszczenie, iż tym, co pozwoliło mu wcześniej przetrwać, była właśnie pamięć. Pamięć, w której ścierały się strach, wyrzuty sumienia, traumatyczne wspomnienia, ale jednak czytelnik, zamykając tom, ma wrażenie, że nad wszystkim dominuje pozytywny przekaz, a poeta uczynił z niej swoistą broń przeciw niesprzyjającemu otoczeniu czy też specyficzną formę autoterapii.

Jiř́ Hanuš w eseju dołączonym do omawianego wyboru akcentuje, iż oprócz szkolnego i strywializowanego ujęcia, które po roku 1989 dostatecznie przybliżyło tragiczne losy poety, stając się zarazem specyficznym balastem, proces , ponownego odkrywania i zakotwiczania pamięci" można postrzegać także - co istotne - w kategorii pozytywów, gdyż sprzyja powrotowi do obiegu czytelniczego również samej poezji autora (Hanuš 2005, s. 314). Powraca więc - w ten sposób, jak widać - kwestia ,pamięci odnalezionej”, stając się niejako wartością dodaną tego typu zbiorów. Walory literackie tomu gromadzącego korespondencję więzienną jednego z najważniejszych poetów czes-

o stylu epistolografa, albo uszanować autonomię gatunkową wypowiedzi listowej, jednakże za cenę wyłączenia $z$ tzw. literatury czystej, albo wreszcie dojść do wnios$\mathrm{ku}$, że ciekawsze od ścisłego wykreślania granic pomiędzy tekstem użytkowym a literaturą czystą jest śledzenie kontaktów i współdziałań między nimi” (Czermińska 1975 , s. 29).

${ }^{18}$ Koncept „obrazu autora” Waltra Benjamina przypomniał m.in.: Petr A. Bílek (Bílek 2006, s. 13). 
kich $^{19} \mathrm{XX}$ wieku sprawiają, iż ze sfery piśmiennictwa użytkowego czy listów stricte prywatnych, można go przenieść na grunt istotnych dzieł epistolograficznych w literaturze czeskiej, a może nawet powszechnej.

\section{Literatura}

A le x a nder Jeffrey C., 2015, K teorii kulturniho traumatu, [w:] Komentovana antologie teoretických textů, red. A. Kratochvil, Praha: Ústav pro českou literaturu AV CR, Akropolis, s. 97-122.

A s s ma n n Aleida, 2015, Od kolektivního násili ke společné budoucnosti: Čtyř modely, jak zacházet s traumatickou minulostí, [w:] Komentovaná antologie teoretických textů, red. A. Kratochvil, Praha: Ústav pro českou literaturu AV ČR / Akropolis, s. 257-279.

B a 1 u c h Jacek, 1993, Wstęp do wydania polskiego, [w:] Havel V., Dopisy Olze, thum. E. Szczepańska, Warszawa-Wrocław: Wydawnictwo Naukowe PWN, s. $5-8$

B e d n á řo vá Jitka, 2005, Něha a mijjení: Vězeňská milostná korespondence Jana Zahradnička, [w:] Vira a výraz. Sborník z konference "...bývalo u mne zotvíráno....". Východiska a perspektivy české křest'anské poezie a prózy 20. století, red. T. Kubíček, J. Wiendl, Brno: Host, s. 67-76.

B íl e k Petr A., 2006, Obraz Boženy Němcové. Pár poznámek k jeho emblematické redukci, [w:] Hodnoty a hranice: svět v české literatuřre, česká literatura ve světě: sbornik přispěvků z III. kongresu světové literárněvědné bohemistiky, Svazek 3. Božena Němcová a jeji Babička, red. K. Piorecký, Praha: Ústav pro českou literaturu AV ČR, s. 11-23.

Če p Jan, Zahradníček Jan, 1995-2000, Korespondence 1931-1948, red. M. Trávníček, Praha: Aula.

C zermińs k a Małgorzata, 1975, Pomiędzy listem a powieścia. „Teksty”, nr 4 (22), s. 28-49.

H a n u š Jiř́i, 2008, Duchovní tváŕ Jana Zahradníčka, [w:] Zahradníček J., Mezi nás prostřená noc. Dopisy z vězení ženě Marii, Brno: Centrum pro studium demokracie a kultury, s. 313-333.

H a v e 1 Václav, 1993, Dopisy Olze, tłum. E. Szczepańska, Warszawa-Wrocław: Wydawnictwo Naukowe PWN.

${ }^{19}$ Małgorzata Czermińska podkreśla: „Uznanie dla autonomicznych wartości literackich listu mogło najłatwiej ujawnić się w badaniach nad korespondencją o niewątpliwych walorach" (Czermińska 1975, s. 30).
Je to s tím Akordem velký kř̌žz. Vzájemná korespondence Timothea Vodičky a Jana Zahradnička, 2017, red. N. Trojková, D. Jirsa, Olomouc: Vydavatelství Filozofické fakulty UP.

K r a t o c h vi 1 Alexander, 2015, Úvod, [w:] Pamět' a trauma pohledem humanitnich věd. Komentovaná antologie teoretických textů, red. A. Kratochvil, Praha: Ustav pro českou literaturu AV ČR, Akropolis, s. 5-11.

M i 1 e r David, 2015, Očistec pamětových studií, [w:] Komentovaná antologie teoretických textù, red. A. Kratochvil, Praha: Ústav pro českou literaturu AV ČR, Akropolis, s. 302-304.

Není dálky... Vzájemná korespondence Františka Halase a Jana Zahradníčka z let 1930-1949, 2003, red. J. Wiendl, J. Komárek, Praha-Litomyšl: Paseka.

N o r a Pierre, 2015, Světový nástup paměti, [w:] Pamět' a trauma pohledem humanitnich věd. Komentovaná antologie teoretických textů, red. A. Kratochvil, Praha: Ústav pro českou literaturu AV ČR, Akropolis, s. 62-72.

O s o ls o b ě Petr, 2005, Zahradnićkova básnická eschatologie a Dantova »komedie«, [w:] Víra a výraz. Sborník z konference »...bývalo u mne zotvíráno..... Východiska a perspektivy české křest'anské poezie a prózy 20. století, red. T. Kubíček, J. Wiendl, Brno: Host, s. 77-90.

P a j ą k Aleksandra, 2014, Polskie poszukiwania i inspiracje Jana Zahradnička, [w:] Proměny polonistiky. Tradice a výzvy polonistických studií, red. M. Benešová, R. Rusin Dybalska, L. Zakopalová a kol., Praha: Karolinum, s. 106-116.

R i c o e u r Paul, 2012, Pamięć, historia, zapomnienie, tłum. J. Margański, Kraków: Universitas.

S kw a r z yń sk a Stefania, 1937, Teoria listu, Lwów: Archiwum Towarzystwa Naukowego we Lwowie.

Tr z y n a d lo w s k i Jan, 1977, List i pamiętnik. Dwie formy wypowiedzi osobistej, [w:] Mate formy literackie, Wrocław: Ossolineum, s. 82-97.

Ve znameni »jadis«... Vzájemná korespondence Jana Zahradnička a Františka Hrubina z let 1937-1950, 2018, red. J. Wiendl, Z. Wiendlová, Př́ibram: Pistorius \& Olšanská

W e i n b e r g Manfred, 2015, Historický přehled, [w:] Komentovaná antologie teoretických textù, 2015, red. A. Kratochvil, Praha: Ústav pro českou literaturu AV CR, Akropolis, s. 12-30.

$\mathrm{Z}$ ahradníč e k Jan, 2008, Mezi nás prostřena noc. Dopisy z vězení ženě Marii, Brno: Centrum pro studium demokracie a kultury.

Z a le s k i Marek, 2004, Formy pamięci, Gdańsk: słowo / obraz terytoria. 